\title{
LAWYERS IN AGENCIES: ECONOMICS, SOCIAL PSYCHOLOGY, AND PROCESS
}

\author{
JONATHAN R. MACEY*
}

I

\section{INTRODUCTION}

Underlying the discussion of the role of the government lawyer that follows lies the premise that lawyers within agencies are fundamentally different than other regulators. A particular regulatory process - and indeed the administrative state in general-would look quite different if we decided to exclude lawyers from the process. Moreover, our explicit or implicit decision about the contours of the role played by lawyers in the administrative state has important implications for our understanding of basic issues, such as the value of science and the value of advocacy. Similarly, excluding other specialists, such as economists or industry experts, also would produce interesting and important changes in the outcomes generated by the administrative state. To put the matter more precisely, there is no question that lawyers' involvement in the administrative process has both costs and benefits. ${ }^{1}$

The purpose of this essay is to explain the nature of these costs and benefits. The first section of the essay draws on insights from social psychology, providing an explanation for why lawyers' perspectives on regulatory issues differ dramatically from those of their non-regulatory colleagues. The second part describes some of the benefits from adding lawyers and lawyers' perspectives to the regulatory mix. In the third part of the article I discuss the costs that lawyer involvement imposes on a regulatory system.

The conclusion is that the inability to quantify the costs and benefits associated with lawyer involvement in regulation makes it impossible to determine with any degree of certainty whether the benefits exceed the costs. On the other hand, the clearly identifiable benefits associated with utilizing lawyers in the regulatory process strongly suggest that it is highly unlikely that the optimal number of lawyers in the regulatory process is zero. It seems equally true,

\footnotetext{
Copyright $\odot 1998$ by Law and Contemporary Problems

This essay is also available at http://www.law.duke.edu/journals/61LCPMacey.

* J. DuPratt White Professor of Law and Director, John M. Olin Program in Law and Economics, Cornell University.

1. Recognition of this point can be found as early as Colonial times, when certain colonies, notably Connecticut, Massachusetts, and Virginia, initially undertook to exclude lawyers and the practice of law in order to remain pure of their corrupting influence. See LAWRENCE FRIEDMAN, A HISTORY OF AMERICAN LAw 81-84, 549-550, 553 (1973). The Fundamental Constitutions of the Carolinas found lawyering repugnant and expressed the view that it was "a base and vile thing to plead for money or reward." Id. at 81 .
} 
however, that at some point the law of diminishing returns ultimately swings the balance to the negative. Similarly, the costs and benefits from lawyer involvement in rulemaking are likely to differ significantly, not only across regulatory agencies, but also within regulatory agencies, with respect to particular issues.

\section{II}

\section{PREFERENCE FORMATION AND THE CREATION OF LAWYERS}

Lawyers differ from others involved in the process of policy formation in two ways. First, the people attracted to law as a profession may be different than other people in some ways. Second, if the process of assimilation into the legal culture that occurs during law school changes the way that people view the world, then the very fact that a law school education is a necessary prerequisite to becoming a lawyer causes lawyers to influence the regulatory process in predictable ways.

\section{A. Who Become Lawyers?}

The law is not a particularly entrepreneurial profession. The process of lawyering to a very large extent involves interpreting and synthesizing cases and statutes in order to make predictions about how decisionmakers (such as judges) will apply such rules to a particular fact pattern. This means law entrepreneurial risk-takers are not likely to be attracted to law schools. This observation also contains common adages about lawyers and the nature of legal advice: Good legal advice is conflated with the notion of conservative legal advice.

Moreover, lawyers are reactive. Clients with real disputes or potential legal problems approach lawyers for advice and counseling. Lawyers then respond with legal advice to the problems presented by the client. For this and related reasons, law is considered to be a reactive service profession whose practitioners serve the needs of its clients.

The structure of the legal profession also reinforces the idea that law is a service industry. Lawyers' professional responsibilities are directed toward their clients, rather than either toward more selfish ends such as selfaggrandizement, or toward more global ends such as justice or efficiency.

Thus, risk-taking and entrepreneurship are not qualities that are likely to be found among the cohort of college graduates who opt for law school. It seems quite likely that those who select for law school are somewhat more risk-averse and non-entrepreneurial than the population as a whole.

This generalization is confirmed by popular impressions about lawyers' earnings. Law is thought to be a profession that provides its membership with a "comfortable" standard of living, but it is not considered a calling in which one is likely to become exceptionally wealthy. Thus, while there are very few, if any, starving lawyers, so too is there a correspondingly small number of very rich lawyers. Bill Gates would never have been able to replicate his earnings 
history if he had followed his father's career into the legal profession. These impressionistic observations are consistent with empirical results finding small positive returns associated with an investment in going to law school. ${ }^{2}$

In addition to these observations about lawyers likely risk-taking proclivities, the sample of the general population interested in law school is also likely to be biased against those who are particularly creative. Those who are especially creative are unlikely to be interested in law school because the law school experience, like the practice of law itself, does not provide much opportunity for creative expression. Typically, law school consists of a highly rigid curriculum of traditional courses. Class discussions involve student participation, but such participation is both highly stylized (the so-called "Socratic Method") and rigidly monitored and controlled by the profession. Students' opportunity for creativity is further reduced by the prevailing system by which law students' performance is evaluated. Law school exams generally take place at the end of each semester and these exams generally provide the sole mechanism for ascertaining the grade that a law student should receive in a particular course. Thus, the law school educational process and the law school examination process do not provide opportunities for creativity. And because the process of educating law students is meant to prepare students for the practice of law, of course one would not be surprised to find that the most creative college graduates do not opt to attend law school.

In addition, students often attend law school to postpone the day on which they must make an ultimate career decision. Law school for such students is a costly mechanism for extending one's undergraduate liberal arts education. From this perspective, the decision to attend law school can be viewed as a hedging strategy for one's career in which a law degree provides the law student with a "put option" whose terms permit the student to pursue a wide variety of careers, while retaining the option to "put" herself into a career in law should the other options prove unattractive. This analysis reinforces the assertion here that law school students represent a biased sample of the general population in the sense that it is systematically risk-averse.

Risk aversion is not the only characteristic that one is likely to find in large numbers among law students. The idea that law students are unusually idealistic cannot be dismissed. After all, the legal system represents a mechanism for engineering social change. For this reason, law school is likely to represent an attractive choice for those interested in affecting social change through government action. Those college graduates who prize entrepreneurship and find governmental intervention in free markets objectionable, however, are likely to be attracted to the idea of a legal education to a much smaller extent.

Finally, it also seems clear that lawyers are less mathematically inclined than other professionals, such as engineers, accountants, doctors, and MBA students. Mathematical skills and abilities are not a prerequisite to the practice

2. See Sherwin Rosen, The Market for Lawyers, 35 J.L. \& ECON. 215, 217-18 (1992). 
of law. Law students may have many talents, including the ability to reason analytically and to marshal arguments in favor of a particular point of view, but mathematical skill, including statistical ability, does not appear to be a particular strength.

The above discussion has focused on law students generally. Many of these points actually assume even more force when applied to that subset of law students inclined to choose careers in governmental service after law school. In particular, the assertions made here about the lack of entrepreneurial proclivities and risk aversion would seem to apply with particular force to governmental lawyers. Similarly, the point that law students are likely to be highly idealistic and to believe in the efficacy of social engineering appear to apply in an especially convincing manner in the context of governmental lawyers.

\section{B. Preference Formation in Law School}

Whatever preferences and belief systems one had before law school are likely to undergo some change during law school. First, a growing body of psychological evidence supports the fact that human preferences are highly malleable and contextual. ${ }^{3}$ This means that an environment such as law school, in which social pressure, competition, and quest for status are intense, are likely to have a significant influence on one's world view. Second, and most importantly, the very choice of law as a vocation is likely to exert a strong influence on one's preferences. Social psychologists have shown that occupational choices, such as the choice to go to law school and become a lawyer, will have a strong influence on one's attitudes and values. ${ }^{4}$ People internalize their vocational roles. Over time the study of law causes people to internalize the perspective of the legal profession, which causes them to lose their objectivity.

The basic idea is that once someone has been in law school for a while, they are likely to embrace the perspective of the legal system as an interest group. Moreover, once the original decision to go to law school and become a lawyer is made, this decision will affect future decisions-future decisions will be made to comport with the initial decision. For example, studies of the decisionmaking process that contributed to the escalation of the Vietnam War showed that leaders paid more attention to new information that was compatible with their earlier decision to make a military commitment in Southeast Asia and ignored information that contradicted those earlier assumptions. As one researcher observed, "[t]here was a tendency, when actions were out of line with ideas, for decision-makers to align their ideas with their actions." become ingrained in the mind of law students, the possibility of altering these

3. For an excellent literature review, see Matthew Rabin, Psychology and Economics, $36 \mathrm{~J}$. ECON. Literature 11 (1998); see also Robert H. Frank, Choosing THE Right Pond: Human BEHAVIOR AND THE QUEST FOR STATUS 30-38 (1985).

4. See Jerold G. Backhan \& Patrick M. O'Malley, Self-Esteem in Young Men: A Longitudinal Analysis of the Impact of Educational and Occupational Attainment, 35 J. PERSONALITY \& SOC. PSYCHOL. 365 (1977).

5. See Ralph K. White, Selective Inattention, PSYCHOL. TODAY, Nov. 1971, at 47, 82. 
beliefs decreases substantially. "[B]eliefs are like possessions," so "[w]hen someone challenges our beliefs, it is as if someone criticized our possessions."6

The theory of "escalating commitments," a well-accepted building block of social psychology, helps explain how the law school experience can shape people's preferences. The decision to attend law school represents, at least in part, a decision to embrace the legal culture. In law school students learn, in addition to substantive legal principles, how to read, to write, and to think like a lawyer. Gradually, over the course of a law school education, law students come to think of themselves as lawyers and as a part of the legal profession. Once law students have accepted certain aspects of legal culture, they will come to identify strongly with that culture. Future decisions reinforce the earlier decision to attend law school and to pursue a legal career. This explains why most law students pursue a career in law upon graduation from law school, despite the fact that many entered law school with no intention of practicing law.

The point, of course, is that a law school education brings with it a complex socialization process in which "civilians" are transformed not only into lawyers, but also into members of an elite, powerful, highly selective, special interest group: the legal profession. Lawyers working in administrative agencies can be expected to have perspectives that represent and reflect the views of the profession.

This argument is supported not only by social psychology, but by economics as well. From an economic perspective, the decision to attend law school is a decision to make a highly specific investment in human capital. After attending law school, changes in the relative levels of supply and demand for lawyers are likely to have a direct effect on the material well-being of a particular lawyer. Moreover, the effects of exogenous shocks effecting lawyer supply and demand are likely to have their greatest impact on newly minted lawyers.

Over time, law schools have responded to the risks associated with specializing in law by broadening the options available to their graduates, such as by transforming from local and regional institutions into national ones. At the same time, federal law has become increasingly important, so lawyers trained for national practice are unable to protect themselves from the risk that changes in national law (such as tort reform or reform of securities laws) will cause a diminution in demand for their services.

Adding-or subtracting-lawyers to or from the mix of professionals involved in the policymaking process at administrative agencies is likely to have an effect on the substantive outcomes generated by that process. Those interested in influencing policy should take the systematic biases of agency lawyers into account when considering the procedural rules that govern agency behavior.

6. Thomas Gilovich, How We Know What ISN'T So: The Fallibility of Human Reason IN EVERYDAY LIFE 85-86 (1991).

7. See David G. MYers, Social Psychology 46-49 (1983). 
On the other hand, inherent professional biases are not unique to the legal profession. Economists have certain structural biases-particularly biases against governmental intervention in market processes, and in favor of market solutions to problems of scarcity and rationing. So, for example, if we take the public policy issue of providing affordable housing to low-income people, the more lawyers that participate in a policy discussion of this issue, the more likely rent-control will be selected as the solution to a housing problem. By contrast, economists would not only be far more likely to reject the use of rent-control, but they also would be more likely to reject the very existence of a long-term housing "shortage:" Because microeconomic theory posits that markets clear where supply and demand curves intersect, if there are a significant number of people who both lack housing and demand it at a particular point in time (keeping in mind that demand is defined by economists in terms of one's willingness to pay), this temporary "excess demand" will be met, first by an increase in housing prices and rents, and soon thereafter by entrepreneurial builders.

Thus, it is not surprising that when politicians have been unhappy with the policy proposals generated by regulatory agencies, they have responded with proposals to change the mix of policy professionals within the agency. For example, when during the 1980s the Securities and Exchange Commission ("SEC") adopted a laissez-faire response to the issue of how unsolicited tender offers should be regulated, many in Congress were concerned. Hostile tender offers, if unregulated, can result in changes in control of U.S. corporations. Such changes in control, while beneficial to shareholders in the target firm, are quite threatening to managers as well as to legislators. Managers are threatened with the loss of their positions; legislators are subjected to political pressure by managers and are concerned that a transfer of control of a corporation in their congressional district could lead to a loss of jobs for voters in their district. It is not surprising that the SEC's free market stance in the 1980s was met with concern in Congress. One proposed solution was to eliminate the SEC's ability to hire economists by eliminating funding for the Commission's Office of the Chief Economist, which is where the SEC's professional economists work. ${ }^{8}$ Similarly, those in favor of creating a more stream-lined administrative process are likely to be those who complain the loudest about having lawyers involved in the agency rulemaking process. Lawyers, of course, are likely to be relatively unsympathetic to these complaints.

\section{III}

\section{LAWYERS IN AGENCIES}

Lawyers in administrative agencies are likely to have values, attitudes, and perspectives different from those found in a random sample of the population.

8. See Jonathan R. Macey, Senators Would Shoot the SEC Messengers, WaLL ST. J., Sept. 10, 1987 , at A8. 
Different, however, does not imply better or worse. Rather, adding or subtracting lawyers (and the influence of lawyers) from the policy- and ruleformation process within an agency is likely to have both costs and benefits. This is consistent with the intuition that, as with other professions, such as scientists, economists, and accountants, the mix of lawyers probably should vary among agencies and within an agency to accommodate not only the need for lawyers' skills, but also the related desire for lawyers' perspectives within the agency.

\section{A. Costs and Benefits of Lawyers in the Administrative Process}

It is widely recognized that, all else being equal, lawyers are likely to add delay to the administrative decisionmaking process. Indeed, the delays associated with legal decisionmaking often cause businesses to decry the use of lawyers as "deal breakers." Lawyers are quick to point out that not every deal should be made. Clearly this is true, and the benefits associated with delay frequently are not fully appreciated.

A recent article by Jon Elster treats the issue of emotions and economics. Professor Elster makes the interesting point that many human emotions are transient. $^{10}$ A straightforward implication of this observation is that the delay associated with adding lawyers to the administrative process is likely to lead to a diminution in those "occurrent emotions that ... have a relatively short duration." "Thus, we would expect that adding lawyers to the process of policyformation will lead to a concomitant diminution in the proportion of agency decisions made on the basis of ephemeral emotions. For example, Elster points out that anger has a relatively short duration. Elster observes (quoting Aristotle and others):

$[\mathrm{M}]$ en become calm when they have spent their anger on someone else. This happened in the case of Ergophilus: though the people were more irritated against him than against Callisthenes, they acquitted him because they had condemned Callisthenes to death the day before.

In the trials of collaborators in German-occupied countries after World War II, those who were tried later generally received milder sentences even when the crimes were similar. ${ }^{13}$ Thus, one benefit of adding lawyers to the mix of policymakers in the regulatory process is that, in cases where human impulses and emotions would lead to hasty and defective decisionmaking, the presence of lawyers will mitigate against too much haste. In particular, the processes created by lawyers within agencies will result in greater deliberation than otherwise.

9. See Jon Elster, Emotions and Economic Theory, 36 J. ECON. LITERATURE 47 (1998).

10. See id. at 70 .

11. Id:; see also NiCO H. FrIJDA, THE EMOTIONS 43 (1986).

12. Elster, supra note 9, at 70-71.

13. See id. at 71 . 
The point is that, while government lawyers generally are derided for causing delay and impeding efficient agency decisionmaking, in fact the delay caused by lawyers brings benefits as well as costs. It is better to avoid having administrative agencies make decisions in anger, for example. The administrative procedures championed by administrative agency lawyers are likely to insure that sufficient time passes between a proposed action and the decision on the proposal, so that bureaucrats' anger is likely to have "spent itself" before affecting policy.

There are three countervailing costs associated with the delays that are likely to be associated with adding lawyers to the administrative process, however first, some emotions are not temporary. With respect to these emotions, the costs of delay are not likely to be offset by a countervailing benefit. Second, not all transitory emotions are bad. Third, the delay associated with adding increasing numbers of lawyers to the administrative process is more likely to contribute to the domination of the process by special interest groups.

\section{B. Long-Lasting Emotions and Self-Deception}

Some emotions are quite durable. The delay associated with lawyering within administrative agencies is unlikely to do much to temper these emotions. For example, both love, which involves "concern for the welfare of one's spouse, but not the strong arousal and action tendencies that we associate with the emotion often referred to as infatuation," and infatuation, which involves "[an] all consuming interest in the other person, heightened energy levels, less need for sleep and food," can in fact endure for years. ${ }^{14}$ More relevant-and disturbing - in the context of the role of administrative agency lawyers, it appears that revenge, contempt and hatred are emotions of long-standing duration:

\footnotetext{
Revenge behavior provides another counterexample to the idea that emotions can be modeled as momentary preferences. In societies where blood feuds are common, revenge can be a lifelong obsession.... Stephen Wilson ... refers to one case in which a man killed six persons who had testified in the trial of his brother, and to another in which a man killed all 14 witnesses who had testified against his brother. Other studies of feuding confirm the view that passion for revenge ... can be a lifetime concern.
}

Worse, not only are these emotions very durable, they also frequently appear to be "all consuming." ${ }^{.16}$ Interestingly, however, Elster asserts that while the "spontaneous urge" to retaliate may be "universal," its transformation into a lifelong passion occurs only in societies where it is amplified by strong social

14. Id. at 71 ; see also, Dorothy TENNOV, LOVE AND LiMERENCE: THE EXPERIENCE OF BEING IN LOVE 140 (1979) (discussing the endurance of love and infatuation).

15. Elster, supra note 9, at 71 (citing STEPHEN WILSON, FEUDING, CONFLICT AND BANDITRY IN Nineteenth-Century Corsica 30, 280 (1988)); see also Milovan Dillas, Land Without JUSTICE (1958) (discussing blood feuds in Yugoslavia); WILlIAM IAN MILlER, BLOODTAKING AND PEACEMAKING: Feud, LAW, AND SOCIETY IN SAGA ICELAND (1990) (discussing blood feuds in Iceland).

16. Elster, supra note 9 , at 71. 
norms. This insight is particularly relevant in the context of government lawyers because the socialization process in law school may serve the valuable end of instilling social norms that minimize the proclivity to act on emotional urges. Alexis de Tocqueville's observation remains apt:

Men who have made a special study of the laws derive from this occupation certain habits of order, a taste for formalities, and a kind of instinctive regard for the regular connection of ideas, which naturally render them very hostile to the revolutionary spirit and the unreflecting passions of the multitude....

The more we reflect upon all that occurs in the United States, the more we shall be persuaded that the lawyers, as a body, form the most powerful, if not the only counterpoise to the democratic element. In that country we easily perceive how the legal profession is qualified by its attributes, and even by its faults to neutralize the vices inherent in popular government. When the American people are intoxicated by passion or carried away by the impetuosity of their ideas, they are checked and stopped by the almost invisible influence of their legal counselors.

Combining Elster's analysis with that of de Tocqueville produces the insight that the human proclivity to seek revenge can be tempered by providing government lawyers with important roles in the legal system. Unfortunately, the durable emotions of contempt and hatred do not similarly seem to be susceptible to being tempered by lawyers. Lawyers constitute an elite profession. ${ }^{19}$ The elitism of lawyers, and the professionalism and superiority inculcated by law school and membership in the bar, contribute to a state of mind in which contempt-viewing others as intrinsically inferior-seems quite possible. The emotion of superiority has had disastrous consequences in the twentieth century. ${ }^{20}$ Moreover, these emotions of superiority, unlike other passions, do not prevent a lawyer from acting in a deliberate, ordered, rational manner. Lawyers are capable of establishing procedures and formal mechanisms for effectuating certain long-lasting prejudices, such as hatred and contempt. Indeed, those in the grip of such durable passions are capable of acting in an instrumentally rational passion, despite the fact that these emotions may be based on irrational beliefs. ${ }^{21}$

Adding lawyers to the policymaking process will bring benefits in the form of preventing short-lived emotions, such as anger, from finding expression in government policy. Unfortunately, however, the addition of lawyers to policymaking will not, by itself, impede long-lived dangerous emotions, such as hatred and contempt, from being transformed into policy. Legal training provides important skills that enable government lawyers to write the regulations or to

17. 1 Alexis de Tocoueville, Democracy in America 273 (H. Reeve trans. \& P. Bradley ed., 1945) (1835).

18. Id. at 278 .

19. Id. ("In America there are no nobles or literary men, and the people are apt to mistrust the wealthy; lawyers consequently form the highest political class and the most cultivated portion of society.").

20. See, e.g., DANiel Goldhagen, Hitler's WiLling EXECuTIONERS (1996).

21. Elster, supra note 9 , at 72 (citing ARISTOTLE, The POlitics AND the Constitution of ATHENS 144 (Steven Everson ed. \& Benjamin Jowett trans., 1996)). 
bring the lawsuits (or, in Elster's words, to "rewrite the script") ${ }^{22}$ that enable the legal system to generate convenient explanations for the superior economic performance of private-sector entrepreneurs that give expression to lawyerly feelings of righteous indignation and moral superiority. This lawyerly proclivity is, of course, in sharp contrast to the proclivity of economists, who are socialized to believe in the value of market forces, the fragility of cartels, and the social utility of entrepreneurship.

Social psychology provides additional support for the argument that lawyers in agencies are likely to find it difficult to sit idly by doing nothing while new technologies and unfettered market forces change the face of society. "[T]he ability of lawyers to justify what they do on the grounds that it provides general benefits to society is nothing short of remarkable." ${ }^{, 3}$ Even the most benign, well-intentioned administrative agency lawyers are likely to believe that the interests of justice are best served by expanding the role of lawyers (and the legal process) in all sorts of decisions. ${ }^{24}$ Rules crafted by agency lawyers may not be designed with the cynical intention of increasing the demand for lawyers generally, but might be designed with the belief that agency lawyers are adding value to the economic system.

Social psychology confirms that government lawyers, like other people, have a strong tendency to find justifications for their own actions and behavior. People generally believe what they want to believe, and that what they do is socially desirable. ${ }^{25}$ Thus, it is unsurprising that lawyers in administrative agencies are likely to think that bringing enforcement actions against successful competitors has social utility, regardless of the reality of the situation. This inclination is likely to be exacerbated by the natural human emotion of envy, which lawyers can transform into regulations that give expression to the natural inclination to transform envy into feelings of moral superiority.

Indeed, the extent of people's ability to transform their belief systems into a set of convictions that are consistent with their professional activities is nothing short of miraculous. An amusing and powerful illustration of this point is provided by Raymond Hyman in his interesting description of how, by acting as a psychic, over time he convinced himself that he had psychic powers:

I started reading palms when I was in my teens as a way to supplement my income from doing magic and mental shows. When I started I did not believe in palmistry. But I knew that to "sell" it I had to act as if I did. After a few years I became a firm believer in palmistry. One day the late Dr. Stanley Jaks, who was a professional mentalist and a man I respected, tactfully suggested that it would make an interesting experiment if I deliberately gave reading opposite to what the lines indicated. I tried this out with a few clients. To my surprise and horror my readings were just as suc-

22. See id. at 69 .

23. Jonathan R. Macey, Civic Education and Interest Group Formation in the American Law School, 45 STAN. L. REV. 1937, 1945 (1993).

24. See id.

25. GILOVICH, supra note 6, at 77. 
cessful as ever. Ever since then I have been interested in the powerful forces that convince us ... that something is so when it really isn't."

Social psychologists have shown that even immoral actions, as well as scientifically unsupportable positions, can be reinforced by the process of verbal commitment and role playing. ${ }^{27}$ For example, when the millionaire heiress Patty Hearst was kidnaped by the Symbionese Liberation Army ("SLA"), she ultimately came to share the views of her captors. As she later explained, "I had thought I was humoring (her SLA captors) by parroting their cliches and buzz words without personally believing in them."28 However, she realized that "[i]n trying to convince them I convinced myself.,"29

\section{The Costs of Discouraging Emotions}

A second problem with eradicating emotions from the policy formation process is that not all temporary emotions are bad. In particular, emotions that we may wish to encourage in governmental agencies, such as generosity and shame may be only short-lived urges that reflect a "short-term change of preferences." on public choice and administrative law, "[w]e seem to lack the capacity for extended sympathy on a continuous basis beyond the family or perhaps the clan.",31

Unfortunately, the fact that adding lawyers to the administrative process is likely to contribute to delay that, in turn, will reduce the natural urges toward generosity and sympathy, does not imply that lawyers will be disinclined to effectuate wealth transfers. Rather, as the burgeoning literature on public choice implies, wealth transfers that reflect the desire to impose differential costs and benefits on rival interest groups, rather than any general generosity on the part of governmental actors, are all too common. Public choice theory models the legal process as one in which regulations and laws are supplied and sold by legislators and bureaucrats to discrete, well-organized special interest groups.

The emotion of envy is important because it may fuel the proclivity for lawyers to write rules that allow them to express the frustrations and feelings of inferiority brought on by this powerful, long-lasting emotion. Jon Elster makes

26. Ray Hyman, Cold Reading: How to Convince Strangers That You Know All About Them, in PARANORMAL BORDERLANDS OF SCIENCE 79, 86 (Kendrick Frazier ed., 1981).

27. See Ellen Tobey Klass, Psychological Effects of Immoral Actions: The Experimental Evidence, 85 PSYCHOL. BULL. 756 (1978).

28. MYERS, supra note 7 , at 50 .

29. Id.

30. Elster, supra note 9 , at 70.

31. Jerry L. Mashaw, Greed, Chaos and Governance: Using Public Choice to IMPROVE PUBLIC LAW 27 (1997).

32. For a general account of public choice theory, see Jonathan R. Macey, Promoting Public Regarding Legislation Through Statutory Interpretation: An Interest Group Model, 86 COLUM. L. REV. 223 (1986). For an excellent account of public choice theory in action, see ELMER Schattschneider, Politics, Pressures and the TarifF: A Study of Free Private EnTERPRISE IN PRESSURE POLITICS, AS SHOWN IN THE 1929-1930 REVISION OF THE TARIFF (1935). 
the following observation, which applies with particular force to administrative agency lawyers because of their ability to write the rules:

To feel envious is to feel inferior. Nobody likes to feel inferior, especially when there is nobody else to blame. To alleviate the feeling of inferiority, people often rewrite the script so as to be able to blame someone else for their situation or to explain the superiority of the other by his immoral behavior. By this dissonance reduction mechanism, the horrible feeling of envious inferiority can be transmuted into the wonderful feeling of righteous indignation.

Similarly, de Tocqueville observed in the context of private citizens that government lawyers are quite likely to

see a man of their own rank in life who rises from that obscure position in a few years to riches and power; the spectacle excites their surprise and their envy, and they are led to inquire how the person who was yesterday their equal is today their ruler. To attribute his rise to his talents or his virtues is unpleasant, for it is tacitly to acknowledge that they are themselves less virtuous or less talented than he was. They are therefore led, and often rightly, to impute his success mainly to some of his vices....

As this article is being written, lawyers in the United States Department of Justice are preparing to file what has been described as an "historic" antitrust action against Microsoft. ${ }^{35}$ Central to the case is Microsoft's dominant position in the market for personal computer operating systems. It is interesting that government lawyers systematically seek out and attempt to destroy firms in dominant market positions. The high-profile litigation involving $A T \& T$ in telecommunications, IBM in mainframe computing, and Drexel Burnham Lambert in high-yield junk bonds immediately come to mind. Government lawyers are likely to regard entrepreneurs such as Microsoft's Bill Gates or Drexel's Michael Milkin with the righteous indignation produced by envy. And the conditioning and norm-formation that occurs in law school do nothing to counteract these proclivities.

In fact, the process of legal training is likely to make administrative agency lawyers indifferent to objective truth and scientific rigor. Lawyers do not rely on the truth, and they do not believe that their job is to produce the truth. Rather, unlike other professionals involved in agency rulemaking, agency lawyers will be indifferent to the truth. This is because lawyers believe

that the truth will be revealed... through a process in which competing advocates pit their skills of persuasion against one another, on behalf of clients in a courtroom or interests in a legislature. Nevertheless, it is not the advocate's goal, as an advocate to bring the truth to light. If the truth is revealed, it is because activities of many advocates, each aiming at something fundamentally different, have been coordinated, like those of Adam Smith's baker and butcher, in such a way as to bring this result about by a kind of invisible-hand mechanism. Although the advocate may contribute to the discovery of the truth by participating in a process of this sort, he does not take its discovery as his own deliberate task. If his work brings the truth to light at all, it does so

33. Elster, supra note 9, at 69-70 (citation omitted).

34. DE TOCQUEVILLE, supra note 17 , at 226.

35. John R. Wilke, Disk Jockying: Suit Against Microsoft by Justice Department Now Seems Imminent, WALL ST. J., May 8, 1998, at A1. 
incidentally and not purposefully. Once again, we are brought back to the Socratic view: in doing what he does, the advocate is indifferent to the truth.

Dean Kronman's observations about the legal profession bring into sharp focus the fact that lawyers have a peculiarly uneasy, indeed schizophrenic place, within the modern administrative agency. The tension arises because lawyers are advocates. The social utility of their role is not a function of what they do, but rather of the results produced by the process in which they participate. Lawyers are supposed to be "pragmatic rather than principled,", while administrative agencies are supposed to be principled, rather than pragmatic. As Richard Wasserstrom has observed, "[t]he fact that the lawyer's words, thoughts, and convictions are, apparently, for sale and at the service of the client helps us, I think, to understand the peculiar hostility which is more than occasionally uniquely directed toward lawyers. The verbal, role-differentiated behavior of the lawyer qua advocate puts the lawyer's integrity into question in a way that distinguishes the lawyer from other professionals." ${ }^{38}$

In sum, the model of lawyer-as-hired-gun is fundamentally at odds with the model of administrative agency as dispassionate, technical, scientific, and truthseeking. Nowhere is this tension more apparent than in the Supreme Court landmark case on judicial power to review administrative decisionmaking, Chevron U.S.A. v. Natural Resources Defense Council, Inc.

At issue in Chevron was the legality of a rule promulgated by the Environmental Protection Agency ("EPA"), called the "bubble policy," in which manufacturers were allowed to install new production equipment despite the fact that such equipment did not meet all of the conditions stipulated in such firms' air quality permits. In order to install such new equipment, however, the manufacturers had to make other, offsetting changes in their production facilities so that the overall quality of the emissions from the plants did not decline.

The Natural Resources Defense Council ("NRDC") challenged the EPA's action, claiming that under the Clean Air Act, which was the source of the EPA's rulemaking authority in the case, each source of pollution within a plant was a so-called "stationary source," and therefore the agency had exceeded its authority by permitting manufacturers to operate without meeting all of the conditions of their air quality permits. ${ }^{40}$ Specifically, the NRDC argued that the Clean Air Act specifically prohibits any increase in emissions from any "stationary source" in areas of the country with particular environmental problems (so-called "non-attainment" areas). ${ }^{41}$ Thus, according to the NRDC, the EPA lacked the authority to issue its bubble regulations in those areas of the country that had been categorized as not-attainment areas, because the

36. Anthony T. Kronman, Foreward: Legal Scholarship and Moral Education, 90 YALE L.J. 955, 963 (1981).

37. Richard Wasserstrom, Lawyers as Professionals: Some Moral Issues, 5 HUM. RTs. 1, 13 (1975).

38. Id. at 14 .

39. 467 U.S. 837 (1984).

40. See id. at 840 .

41. See id. at 841 . 
bubble regulations permitted companies to install new equipment that merely maintained, rather than improved, the quality of the air, despite the provisions of the Clean Air Act. ${ }^{42}$ An additional logical problem with the EPA's policy was that the agency's actions resulted in a confusing state of affairs in which the agency treated each source of pollution as a "stationary source" under the Clean Air Act for some purposes, but treated an entire manufacturing or production facility as a stationary source for its bubble policy. ${ }^{43}$

The Supreme Court in Chevron upheld the EPA's bubble policy despite these objections. The Court decided that the EPA, as the agency with the technical expertise in the field and the legislative authority to promulgate environmental policy, should enjoy substantial deference in interpreting the law. ${ }^{44}$ In other words, in Chevron the Supreme Court permitted the administrative process to trump the judicial process so long as the administrative decision being challenged was within the agency's jurisdiction and was "reasoned."

The Supreme Court's Chevron decision is considered one of the most important administrative law decisions of the decade, not only because of the rule it articulates regarding the allocation of authority to review agency decisions, but because of the vision of the administrative state conveyed in the holding. The latter is relevant to the role of lawyers in administrative agencies.

In essence, Chevron presented the Supreme Court with a clear choice between the relative benefits of the adversary process and the technical expertise of administrative agencies such as the EPA. In upholding the right of administrative agencies' virtually unfettered discretion to interpret statutes involving major policy trade-offs, the Supreme Court concluded that the social value of the adversary process was lower than the social value of the EPA's internal cost/benefit analysis.

To illustrate the point more clearly, it is useful to imagine the Supreme Court's decision in Chevron as reflecting the extreme end of a continuum of possible perspectives on the relative value of lawyers in the administrative state. At one end of the continuum would be the view that lawyers add a lot to the quality of the decisionmaking process within agencies. As Dean Kronman observed, ${ }^{46}$ the core justification for lawyers is that, in their role as advocates, their activities generate truth. It was this perspective that was rejected in Chevron. It is difficult to overstate the importance of the model of lawyers as advocates to an understanding of the role of lawyers in the administrative process. Absent a role for advocacy in the administrative process, the justification for the lawyer disappears, because advocacy is what lawyers do. It is their comparative advantage. As Monroe Friedman has observed, "truth is a basic value, and the adversary system is one of the most efficient and fair methods designed

\footnotetext{
42. See id.

43. See id.

44. See id. at 865-66.

45. See id. at 865.

46. See supra note 36 and accompanying text.
} 
for determining it. That system proceeds on the assumption that the best way to ascertain the truth is to present to an impartial judge or jury a confrontation between the proponents of conflicting views, assigning to each the task of marshalling and presenting the evidence in as thorough and persuasive way as possible." "4

At the other end of the continuum lies the perspective that the Court embraced in Chevron. There is no particular place for advocacy in this vision, and thus there is no particular place for lawyers. In place of the advocacy model, the Court adopted a bureaucratic model, embracing a vision of the administrative process in which rational, scientific policymakers benignly calculate the costs and benefits of alternative policies on the basis of their specialized technical expertise. Following such a cost/benefit calculation, the experts within the administrative agencies adopt the policies that maximize overall social welfare within whatever broad policy formulation the legislature has provided.

According to the Court in Chevron, to reject this model and to replace it with the old adversary model would be nothing short of corrupt because it would substitute the expertise of the administrative agencies for the personal policy preferences of the judges. ${ }^{48}$ This conclusion represents an explicit rejection of the proposition that the adversary system in general or lawyers in particular add value to the decisionmaking process within administrative agencies. The Court's emphasis on its own lack of expertise, in comparison with the expertise of professionals within administrative agencies such as the EPA, is particularly telling:

Judges are not experts in the field and are not part of either political branch of the Government. Courts, must, in some cases, reconcile competing political interests, but not on the basis of the judges' personal policy preferences. In contrast, an agency to which Congress has delegated policy-making responsibilities may, within the limits of that delegation, properly rely upon the incumbent administration's views of wise policy to inform its judgment.

While the Court's explanation is framed in terms of the deficiencies of judges, the holding in Chevron nevertheless represents a rather stunning rejection of the value added by lawyers to the administrative process. It is important to link this result to the all-important "paradigm shift", within the administrative state from policymaking by adjudication, in which lawyers within administrative agencies play an important and salutory role, to policymaking by rulemaking, in which general rules and standards are adopted and lawyers are basically superfluous. The shift from adjudication to rulemaking has been characterized as "one of the greatest inventions of modern government," many have embraced the view that the transition to rulemaking would make

47. MONROE H. FREEDMAN, LAWYERS' ETHICS IN AN ADVERSARY SYSTEM 3-4 (1975).

48. See Chevron, 467 U.S. at 843-44.

49. Id. at 865 .

50. MASHAW, supra note 31 , at 158 .

51. KeNNETH CULP DAVIS, ADMINISTRATIVE LAW $\$ 6.15$ (1970). 
federal policymaking "simultaneously... more rational and more democratic." ${ }^{52}$

Mashaw has described the transition succinctly:

As late as the presidency of John F. Kennedy, the principal image of federal administrative action was the adjudication of a case-a prosecution by the Federal Trade Commission, an enforcement action by the National Labor Relations Board, a licensing proceeding before the Federal Communications or Federal Power Commissions, or a rate proceeding at the Interstate Commerce Commission. More than thirty years later, when Americans think of "regulation" they tend to think of the adoption of general rules concerning workplace safety by the Occupational and Safety Health Administration, or of rules governing air or water quality by the Environmental Protection Agency. Nor is rulemaking the exclusive province of post-New Frontier agencies designed with that regulatory technique prominently in mind. The politically salient activities of old-line agencies--Federal Trade Commission regulation of charm school and funeral home practices, or Federal Power Commission deregulaţion of natural gas pipeline prices - often feature rulemaking rather than adjudication.

The point here is straightforward. The paradigm shift from adjudication to rulemaking, like the judicial approach in Chevron, reflects not only a change in perspectives about the role of the regulatory state, but also a change in the view of the relative merits of lawyer involvement in the administrative state. Lawyers have a clear comparative advantage in an agency process dominated by adjudication. By contrast, the role of lawyers in an agency process characterized by rulemaking is far from clear.

The shift to an agency process dominated by rulemaking reflected an embrace of the idea of a disinterested "science" of rulemaking, in which quality of the decisions generated by technological sophistication triumphs over the quality of the decisions generated by the adversarial process. By contrast, "case-bycase adjudication ... requires little if any technological sophistication." core justification for delegations of legislative power to administrative agencies is that the benefits of the rulemaking expertise of administrative agencies outweigh the benefits of the adjudicatory process. Faith in bureaucratic expertise reflects, at least in part, a faith in the efficacy (and morality) of central planning. Faith in adjudication reflects, at least in part, a faith in the Darwinian process of lawyering ${ }^{55}$ - and markets.

The above discussion also has implications for legal ethics within administrative agencies. One of the oldest tenets of legal ethics is that lawyers are not morally responsible for the acts of their clients. ${ }^{56}$ Yet the rulemaking routinely performed by administrative agencies in the modern administrative state casts them undeniably in the role of moral actors fully accountable for their decisions. Thus, it would seem that lawyers working in administrative agencies involved in rulemaking-particularly in a world governed by the holding in Chev-

52. MASHAW, supra note 31 , at 159.

53. Id. at 158 (citations omitted).

54. Jerry L. Mashaw \& David L. Harfst, The Struggle for Auto Safety 11 (1990).

55. See Kronman, supra note 36 and accompanying text (analogizing the role played by lawyers in producing truth with the invisible hand of free markets).

56. See GeOrge SharswoOd, An EsSAy ON Professional Ethics 83-84 (5th ed. 1884). 
ron-have, or should have, different ethical obligations than lawyers working in administrative agencies involved in "mere" adjudications. Lawyers involved in mere adjudications need have no special or unique moral obligations different from other lawyers. As in the standard conception of government lawyers, the ethical duties of such lawyers properly is to their client, which in this case is the government.

In the adjudicatory context, there is no need to impose on government lawyers any new moral obligations to act morally or to serve the ends of justice. By contrast, in the rulemaking context, government lawyers are supposed to be weighing both the costs and the benefits of their actions when formulating rules. The sort of dispassionate balancing of interests that is intrinsic to rulemaking comes naturally to social and natural scientists such as economists and chemists, but it is not a skill that is taught in law schools or that is even considered particularly relevant to the practice of law.

The Chevron decision is not an unambiguous statement by the Supreme Court about the role of lawyers or about the Court's confidence in the ability of administrative agency experts to make optimal policy choices. In fact, scholars have roundly criticized the rulemaking model and have stressed the need for judicial review of agency action due to concerns about agency bias and about the influence of powerful special interests on the rulemaking process. ${ }^{57}$ As the polity became more familiar with the costs and benefits to society from the administrative state that arose in the wake of the New Deal, voters have become more realistic about the short-comings of the regulatory process. The response of thoughtful observers of the regulatory process often has been to encourage greater use of the adversary process as a means for ameliorating the shortcomings of the outcomes of the agency rulemaking process. For example, Cass Sunstein has argued that modern administrative law has evolved into a mechanism designed to encourage not only better deliberation within agencies, but also judicial policing of agency decisionmaking. ${ }^{58}$

\section{Administrative Procedures and the Domination of the Administrative Process by Special Interest Groups}

A recurring problem is that rulemaking within administrative agencies can be compromised by the influence of powerful special interest groups. This section links the points previously made about lawyers and process within administrative agencies with ideas from the branch of political science known as "positive political theory" ("PPT") $)^{59}$ in order to make a new point about the

57. See Richard B. Stewart, The Reformation of American Administrative Law, 88 HARV. L. REV. 1669, 1711-16 (1975); Cass R. Sunstein, Interest Groups in American Public Law, 38 STAN. L. REV. 29 (1985).

58. See Sunstein, supra note 57, at 63; Cass R. Sunstein, Deregulation \& the Hard-Look Doctrine, 1983 SuP. CT. REV. 177.

59. See Jonathan R. Macey, Separated Powers and Positive Political Theory: The Tug of War over Administrative Agencies, 80 GEO. L.J. 671 (1992) [hereinafter Macey, Separated Powers]; Jonathan R. 
role of lawyers in administrative agencies. Applying the insights of positive political theory to the observations that adding lawyers to the process of creating and applying administrative law will affect outcomes in predictable ways leads to the conclusion that Congress can use its ability to control the supply of lawyers within agencies to control the future behavior of the bureaucrats in those agencies.

One of the core issues addressed in PPT is how the politicians who create administrative agencies can constrain the behavior of bureaucrats who manage the agencies on a day-to-day basis. ${ }^{60}$ The problem that Congress faces is known as "bureaucratic drift;" it relates to the specific concern that future changes in administrative agency policies will be inconsistent with the original expectations of the legislation's intended beneficiaries. From a public choice perspective, it is easy to see why bureaucratic drift is a problem for politicians: Interest groups and others will be unwilling to provide political support for politicians in exchange for legislation if they fear that the bureaucrats running the agencies will be wholly autonomous from congressional control. Interest groups would fear that they would not be able to exercise sufficient influence over the agency, or, more accurately, that they would have to expend significant resources at the agency level (rather than at the congressional level) to obtain their preferred policy outcomes.

Concerns over bureaucratic drift manifest themselves in a variety of ways. The legislative veto, which allows Congress to retain the right to invalidate agency actions after delegating rulemaking authority to an agency is, perhaps, the most obvious example of a Congressional strategy aimed at controlling bureaucratic drift. In addition to this crude and constitutionally suspect device, however, PPT reveals a variety of ways that lawyers within agencies help Congress control bureaucratic drift. Interestingly, in fact, most of the mechanisms that political scientists have identified to control bureaucratic drift are the creations of agency lawyers. These inventions include the prohibitions on ex parte contact with agency officials, the legislatively mandated standards for judicial review, the assignment of burdens of proof in challenges to agency decisions, complex rules regarding allocation of discretionary budgetary funds, and delays built into the administrative process by legal requirements for notice, comment,

Macey, Organizational Design and Political Control of Administrative Agencies, 8 J.L. ECON. \& ORG. 93 (1992).

60. See, e.g., Murray J. Horn \& Kenneth A. Shepsle, Commentary on "Administrative Arrangements and the Political Control of Agencies": Administrative Process and Organizational Form as Legislative Responses to Agency Costs, 75 VA. L. REV. 499, 505-08 (1989) (employing assumption of "intelligent foresight" to conclude that elected politicians in creating agencies devise initial enactments which will protect against the influences of bureaucrats and subsequent political coalitions); Matthew D. McCubbins et al., Structure and Process, Politics and Policy: Administrative Arrangements and the Political Control of Agencies, 75 VA. L. REv. 431, 481 (1989) (concluding that legislatively imposed procedural constraints play a critical role in controlling bureaucratic agents) [hereinafter McCubbins et al., Structure and Process]; Matthew D. McCubbins et al., Administrative Procedures as Instruments of Political Control, 3 J.L. ECON. \& ORGANIZATION 243, 273-74 (1987) (emphasizing that elected politicians should use administrative procedures in addition to, or instead of, sanctions to reduce monitoring costs and to increase bureaucratic compliance). 
and public hearings on proposed agency action. ${ }^{61}$ Political scientists have identified and explained all of these standard features of modern administrative law with the observation that they "contribute to the creation of a political environment that causes agency decisions to mirror the political equilibrium at the time of the original enactment."

Lawyerly proclivities are a natural by-product of the fact that lawyers are trained in law school to place a very high value on the benefits of an adversarial process. Fair procedures are important to lawyers. And, as suggested by Part II of this essay, lawyers, for reasons well known to social psychologists, are likely to register the social benefits associated with creating such procedures, but they are likely systematically to ignore or to undervalue the costs associated with these systems. Thus, for example, the lengthy notice-and-comment provisions and other legally created procedural mechanisms satisfy lawyerly proclivities for the creation of a "fair" process necessary for the adversarial process to work. These same procedures also create a variety of mechanisms by which the targeted special interest group beneficiaries of legislation can notify politicians when an agency generates outcomes that deviate from the interests of the beneficiaries, thereby triggering formal investigations and other legislative responses. ${ }^{63}$

Two insights emerge from this analysis. First, of course, it is not surprising that Congress-even when it is in the hands of Republicans-demonstrates a lack of interest in parroting the general public's disdain for lawyers. The rules created by lawyers help Congress by controlling bureaucratic drift. Second, and more generally, this analysis helps to explain why bureaucratic inefficiencies is tolerated by Congress. What often appear to outsiders (particularly nonlawyers) as useless procedures that produce mind-boggling delays often turn out to be subtle mechanisms for controlling bureaucratic drift.

To summarize, the proposition that procedural norms are used to control bureaucratic drift is one of the foundational principles of PPT. However, PPT has had little to say about the source of the procedural norms that are so important to Congress. Lawyers are often the source of these norms. Thus, the proclivities lawyers toward lawyer-centric, process-based rules, provides a concise explanation for why lawyers are essential to bureaucracies. Lawyers are essential to bureaucracies because they have the specialized skills and the psychological inclination to develop procedural rules necessary to control bureaucratic drift. And as positive political theory makes clear, absent the ability to control bureaucratic drift, Congress would have few incentives to erect the modern administrative state.

61. See McCubbins et al., Structure and Process, supra note 60, at 440-34.

62. Macey, Separated Powers, supra note 59, at 672.

63. Matthew D. McCubbins \& Thomas Schwartz, Congressional Oversight Overlooked: Police Patrols Versus Fire Alarms, 28 AM. J. POL. SCI. 165 (1984). 


\section{E. An Agency Without Lawyers?}

One of the basic objectives of this essay has been to develop the observation that changing the mix of professionals within an administrative agency will have tangible effects on agency policies and procedures. Congress is aware of this fact, as demonstrated by congressional efforts to control the number of economists in the SEC.

It is interesting to ponder what an administrative agency would be like if lawyers, rather than economists, were excluded. While a rule banning lawyers is extremely unlikely given the political power of the organized bar (and the fact that members of the profession, sitting as judges, would be able to evaluate the constitutionality of such a ban), considering the effects of a ban on lawyers in agencies brings into sharp focus the arguments being made here about the role played by lawyers within agencies.

Since all agencies are different, the mental experiment of imagining an agency without lawyers requires selecting, more or less at random, some agency for consideration. The SEC is a good example because it is familiar, and because many of the professional tasks performed by the SEC could be done either by lawyers or by economists. In particular, the five-member Commission itself has had, over the years, a mix of lawyers, economists, and executives from Wall Street. Interestingly, the rules of the Commission require that there be a mixture of Republicans and Democrats on the Commission. The ostensible purpose of this rule is to promote balance among rival political factions in the agency's rulemaking practices. However, there is no requirement that balance be obtained with respect to the mixture of professionals on the Commission. This seems odd in light of the fact that professional affiliation is far more likely than party affiliation to affect one's perspectives on policy. ${ }^{64}$

Banning lawyers within an agency such as the SEC would have the following likely effects. First, there would be a sharp decline, perhaps to the point of extinction, of adjudication as opposed to rulemaking. Similarly, there would be a sharp increase in the propensity of agencies to embrace certain extreme views about the efficacy of market processes versus central planning. Finally, the likelihood of simple agency capture by special interest groups would increase, rather than decline, within agencies should lawyers be excluded from the process.

First, lawyers are likely to place more value on the salutory effects of adjudication due to their faith in the outcomes generated by the adjudicative process. $^{65}$ On the other hand, lawyers are likely to have the same faith in the scientific methods that provide the justifications for rulemaking. Thus, for example, a decline in the number of lawyers at the SEC might account for the recent ef-

64. See Jonathan R. Macey, The Role of the Democratic and Republican Parties as Organizers of Shadow Interest Groups, 89 MICH. L. REV. 1 (1990) (describing the lack of ideological focus of modern political parties).

65. See supra text accompanying notes 53-58. 
forts by the SEC to regulate alternative trading systems. ${ }^{66}$ This major regulatory initiative represents a faith in the power of regulators to understand and control innovation and market forces that lawyers would not share. In other words, while lawyers within agencies might not trust market forces, their belief in the Darwinian advocacy process is likely to cause them to similarly doubt the efficacy of central planning. One probable effect of removing lawyers from the advocacy process would be to remove an important mediating influence from the regulatory process. Non-lawyers are likely to be more prone than lawyers to embrace extreme views, either about the efficacy of market forces or the efficacy of central planning.

In his article on the economics of stare decisis, Professor Kornhauser, an economist, raises the interesting question of what justifies adherence to a prior legal decision known to be wrong. ${ }^{67}$ This question is a strange one for lawyers. As an economist, Professor Kornhauser is quite comfortable with the notion that the social science methodology can produce right answers and wrong answers. By contrast, lawyers will be more skeptical about our ability ever really to know with absolute certainty what the right answer is in a particular case. Indeed, to assume that we can know that a particular decision is wrong removes much of the justification for having lawyers involved in administrative decisions. The process-based values near to the heart of lawyers are hardly necessary if we can achieve truth with certainty.

For example, the SEC takes a process-based approach to the regulation of new public offerings. The SEC's rules start with the premise that regulators are unable to distinguish between securities that should be sold to the public and those that should not be. The SEC's regulatory framework takes a processbased approach which demands only that issuers of securities make the requisite disclosures of information that investors probably will find relevant. Market forces, particularly the market's ability to protect consumers by setting very low prices for securities with significant risk characteristics, are thought to be sufficient to protect consumers. This process-based approach is appealing to lawyers. But the current regulatory structure does not please either freemarket purists, who would prefer no regulation of any kind, including the regulation of disclosure, or ardent statists, who would prefer to have a regulatory regime that permitted bureaucrats to decide on whether a particular securities offering should be marketed to the public in the first place.

Deleting lawyers from the SEC or other regulatory agencies is likely to have a mediating effect on the ideological propensities of agency bureaucrats.

66. See Regulation of Exchanges and Alternative Trading Systems, Exchange Act Release No. 3439884, 67 S.E.C. 2339 (April 17, 1998). The Commission proposes sweeping new regulations which, if implemented, would effect radical changes in the way that stock exchanges, brokerage firms, and electronically linked trading systems compete with one another. See id.; see also Jonathan R. Macey \& Maureen O'Hara, Regulating Exchanges and Alternative Trading Systems: A Law and Economics Perspective, J. LEGAL STUD. (forthcoming Jan. 1999).

67. See Lewis Kornhauser, An Economic Perspective on Stare Decisis, 65 CHI.-KEnT L. REV. 63 (1989). 
This is because the process-based approach favored by lawyers is fundamentally incompatible with extremist views. Lawyers are by nature Solomonic. They are trained to believe that there are two sides to every point, and that the power of an argument, rather than the power of truth, often will win the day. This makes lawyers, particularly those acting in the role of judges, naturally reluctant to adopt extreme positions. This, in turn, makes it somewhat less likely that lawyers will be captured by particular constituencies of the agencies in which they work.

On the other hand, lawyers are likely to be oblivious to the costs associated with the procedural rules that they promulgate within agencies. The costs associated with complying with the new procedural rules created by lawyers are viewed by the people and firms that must comply with them as costs, but they are not viewed by lawyers as costs. The complex tests developed by courts and agencies impose transaction costs on regulated entities, but from the perspective of the legal profession these costs translate into an increase in demand for the services provided by lawyers. Even lawyers within agencies are not likely to view these costs in the same way as non-lawyers because these costs also increase the relative importance of the role played by lawyers within agencies. This insight, of course, closely corresponds with the widely held intuition that removing lawyers from participation in the regulatory process would result in less "bureaucracy," that is in less burdensome regulation.

\section{IV}

\section{CONCLUSION}

Lawyers have a certain world view. The process begins in law school, and can be explained as self-interest and subtle psychological adaptation. The lawyers' approach to problem-solving is worth talking about when discussing the role of lawyers in the administrative state.

Lawyers are inclined to see the benefits of advocacy and the value of establishing rules and procedures that ensure the fairness of proceedings. By contrast, social scientists such as economists are relatively more inclined to believe in the value of the scientific method. Our own visions of the relative merits of these contrasting methodologies inevitably will inform our views about how the administrative state ought to be constructed. Those inclined to the view that advocacy will produce truth will prefer adjudication to rulemaking. Those inclined to the view that scientific method is the best method for resolving uncertainty about the best social policies to pursue will prefer rulemaking over adjudication.

Both methodologies have problems, of course. Those who favor adjudication often fail to appreciate how cognitive biases, prior assumptions, differential resources can affect the outcomes generated by even the most ostensibly fair adjudicatory process. Similarly, those who favor adjudication are likely systematically to underestimate the costs of a system of adjudication. They are 
likely to see only the benefits, and not the costs associated with additional procedural safeguards.

Far from out-competing the system of adjudication, the dramatic shift from adjudication to rulemaking that occurred during the 1960 s and $1970 \mathrm{~s}$ in the United States was never particularly successful. Observers of the bureaucratic process increasingly have recognized that rulemaking within bureaucracies is just a junior version of the central planning and economic command and control systems that failed so flamboyantly in the former Soviet Union and Sovietbloc countries. There are multiple problems with rulemaking in bureaucracies that are just now coming to light. Above all, bureaucracies do not provide suitable incentives for efficient rulemaking. In particular, the susceptibility of bureaucracies to pressure from and, on occasion, even capture by, special interest groups within their regulatory jurisdiction. It is because of the failures of rulemaking that the bureaucracies that

experimented with rulemaking during the 1960 s and 1970 s as a response to charges of inefficiency, unfairness, and lack of accountability have largely returned to their more familiar adjudicatory processes. The machinery of federal rulemaking is widely viewed as so creaky and accident-prone that administrators will resort to almost any other technique to attempt to get their jobs done.

Unfortunately, it seems, there simply is no way to regulate that does not involve substantial costs. The point of this essay has been to supply some new insights into the costs and benefits of adding lawyers to the regulatory process. These insights can, in turn, help us understand not only why lawyers do what they do, but also how they are used by political actors within the modern administrative state.

68. MASHAW, supra note 31 , at 159. 
HeinOnline -- 61 Law and Contemp. Probs. 1321998 